\title{
THE IMPLEMENTATION OF INNOVATIVE LEARNING MODELS TOWARDS THE SKILL OF STUDENTS SCIENCE PROCESS ON PHYSIOLOGY CLASS
}

\author{
Supramono \& Rita Rahmaniati, Supardi \\ Biology Education Program, Department of PMIPA, Faculty of Teacher Training and Education, University of \\ Palangkaraya, Palangkaraya, Indonesia \\ Supramono40@yahoo.co.id \\ Study Program: Teacher Education of Elementary School, Faculty of Teacher Training and Education, \\ Muhammadiyah University of Palangkaraya, Indonesia \\ rahmaniatirita@yahoo.co.id
}

\begin{abstract}
This study aimed to examine: (1) the influence of the implementation of inquiry model toward the skill of student science process of Biology Education students of Palangka Raya university, (2) the influence of PBM model toward the skill of student science process of Biology Education students of Palangka Raya university, (3) the influence of GI type cooperative learning toward the skill of student science process of Biology Education students of Palangka Raya university, (4) the difference of influence of inquiry model, PBM, GI toward the skill of student science process of Biology Education students of Palangka Raya university. The design of the research used of pretest and posttest control group design. The sample of the research was the students who take the plant physiology class. The data were collected by written tests and observations about the students' science processes. Unovariate of covariance analysis (anacova) was used in data analysis of learning outcome of science process. The research results showed that there are a significant influence of innovative learning models toward the student science process, which are of inquiry model of score $\mathrm{F}=34.978$; $\mathrm{p}=0.000 ;$ PBM model of score $\mathrm{F}=24.636 ; \mathrm{p}=0.000$; and cooperative learning model of type inquiry group of score $\mathrm{F}=9.361 ; \mathrm{p}=0.030$.
\end{abstract}

Keywords: inquiry, PBM, GI, KPS

Trianto (2007) states some of innovative learning models based on constructivist paradigm, they are: (1) Reasoning and Problem Solving model; (2) Inquiry Training model; (3) Problem-Based Instruction model; (4) Conceptual Change Learning model; (5) cooperative learning of Group Investigation type; (6) problem-based learning model; (7) Jurisprudential Research model; and (8) Social Research model.

Creativity needs to develop through a good learning situation where teachers encourage the curiosity of students in creating and imparting a new function toward something that exists, students are trained to master self-inquiry techniques and are given the opportunity to conduct experiments (Depdiknas / National Education Board, 2003). The inquiry model, Problem Based Learning (PBM) and cooperative learning of Group Investigation type or group investigation are models of learning activities that can improve the students' science process because the students are given opportunity to have experiments.

The inquiry model begins with a confusing phenomenon that encourages the individual to find out the means of the phenomenon. They naturally desire to understand the phenomenon. To understand to the phenomenon, they go through the process of thinking and more skillfully connect the data into concepts and how to use these concepts into identification of causal principles. So, in the case, it is more emphasis on the process of inquiry and inquiry strategy and is not on the content and explanations of the problematic situation (Rampengan, 1981). And then, the choosen of inquiry model is appropriate in a science learning process because students go through many stages of the science process. 
Group Investigation is one of cooperative learning that emphasize the students participation and activities to find out their own learning materials (information) that will be learned through the available materials, such as textbooks or the internet. Students are involved since the planning, both in determining the topic and how to learn through investigation. The learning model requires students to have good communication skills and group process skills. Cooperative learning of Group Investigation type is able to train the students to improve the ability of independent thinking. Active student involvement may be monitored since the first stage until the final stage of learning (Kiranawati, 2007). Cooperative learning of Group Investigation type requires students to have good communication skills and group process skills.

Problem-Based Learning on its application emphasizes on active student involvement, is more inductively orientated than deductive, and discovery the knowledge by students or their own development. It does not give ideas or theories about the world, which is the way teachers do when using direct learning, but teachers use inquiry or problem-based learning approaches, deliver questions to students, and allow students to arrive at ideas or their own theories (Nur, 2011). All the stages of students do in the PBM may not be separated from the process skills, and able to improve the skill of student science process.

\section{METHOD}

The research was quasi experimental research, with the design of pretests and posttests control group design. The research design format is presented in Table 1.

Table 1. Pretest-Posttest Control Group Design

\begin{tabular}{|c|c|c|c|}
\hline Group & Pretest & Variable & Posttest \\
\hline Experiment I & 0 & $\mathrm{X}_{1}$ & $\mathrm{P}$ \\
\hline Experiment II & 0 & $\mathrm{X}_{2}$ & $\mathrm{P}$ \\
\hline Experiment III & 0 & $\mathrm{X}_{3}$ & $\mathrm{P}$ \\
\hline
\end{tabular}

Where:

O : pretes of experimental group of I, II, III and control

$\mathrm{P} \quad$ : posttes of experimental group of I, II, III and control

$\mathrm{X}_{1} \quad$ : Lecturing using inquiry learning model

$\mathrm{X}_{2} \quad$ : Lecturing using PBM learning model

$\mathrm{X}_{3} \quad$ : Lecturing using cooperative learning of type GI

Variables in the study consisted of independent and dependent variables. There were three independent variables, which are (X1) inquiry learning model in experimental group I, (X2) Problem Based Learning model on learning in experimental group II, and (X3) Cooperative learning type of group investigation on learning in experimental group III. The dependent variable consisted of six skills of the science process, which are (Y1) Observing, (Y2) Classifying, (Y3) Using the Tool, (Y4) Experimenting, (Y5) Predicting, and (Y6) Communicating. The control variables consisted of the students' initial abilities and the same of learning materials in teaching for all groups.

The population of the research was all students of Biology Education of FKIP UNPAR (Faculty of Teacher Training and Education, University of Palangkaraya). The sample of the research was the students of biology class who take the plant physiology 
class.

RESULTS

The research results on the implementation of Inquiry model, Problem Based Learning, Cooperative learning of Group Investigation type toward the student Science Process in the lecture of Plant Physiology obtained the scores' skill data of science process that measured on skills, involve: observing, classifying, using tools, experimenting, predicting and communicating. The score of each group of students is described as follows.

1. The Influence of implementation of Inquiry model on plant physiology class towards the skill of student science process

Based on the calculation of the total score of science process obtained average score of postest in the inquiry model of 6.73 with the category of medium and the control class obtained score of 5.09 with the category of less. The calculation results of the pretest - posttest of students' science process are presented in Table 2.

Table 2. Calculation of Average score of Pretest-Posttest of Student Science Process in Inquiry Class and Control

\begin{tabular}{|l|c|c|c|c|}
\hline \multirow{2}{*}{} & \multicolumn{2}{|c|}{ Inquiry Model } & \multicolumn{2}{c|}{ Control } \\
\cline { 2 - 5 } & U1 & U2 & U1 & U2 \\
\hline Average Score & 3.203 & 6.734 & 3.814 & 5.086 \\
\hline Description & Bad & Medium & Bad & Less \\
\hline Increasing & \multicolumn{2}{|c|}{3.531} & \multicolumn{2}{c|}{1.271} \\
\hline Effectiveness (\%) & \multicolumn{2}{|c|}{52.44} & \multicolumn{2}{c|}{24.99} \\
\hline
\end{tabular}

Where: $\mathrm{U} 1=$ pretest and $\mathrm{U} 2=$ posttest

Increasing the score $(\Delta \mathrm{E})$ is the difference between pretest and posttest score (U2-U1).

The effectiveness level of the learning model is the increasing of the scores of each model and minus to the increasing of score in the control class or $(\Delta \mathrm{E} / \mathrm{U} 2) \times 100 \%$.

Table 2 shows that there is a difference in the score increasing between the experimental class I and the control class by score of 3.531 for inquiry model and 1.271 for control class.

And then, the results of pretest and posttest in control class and experimental class were analyzed using the anacova statistic test, by controlling the pretest, shows that there is a significant effect of the learning model on the science process $(F=34.978 ; p=0.000)$. The result of the difference significance test of the influence of inquiry model compare to control class is presented in table 3 .

Table 3. Results of Significance Test of Model Influence to Science Process

\begin{tabular}{|l|l|c|c|}
\hline \multicolumn{2}{|c|}{ Class } & Sig & Description \\
\hline Experiment I (Inquiry) & Control & 0.001 & Significant \\
\hline
\end{tabular}

Table 3 shows that there is a significant difference between the experimental class I (inquiry) and the control class by the p score less than 0.05 . The effectiveness test result of the difference of learning model toward the science process shows the inquiry model is significantly more effective compare to the control class. 


\section{Influence of implementation of PBM model to Student Science Process}

Based on the calculation of the total score of science process obtained the average score of posttest on the PBM learning model of 6.83 with the category of medium and control class obtained score of 5.09 with the category less. The calculation results of the pretest - posttest of students' science process are presented in table 4.

Table 4. Calculation of average score of Pretest - Posttest of Student Science Process in PBM Class and Control

\begin{tabular}{|l|c|c|c|c|}
\hline \multirow{2}{*}{} & \multicolumn{2}{|c|}{ Model of PBM } & \multicolumn{2}{c|}{ Control } \\
\cline { 2 - 5 } & U1 & U2 & U1 & U2 \\
\hline Average Score & 3.625 & 6.839 & 3.814 & 5.086 \\
\hline Description & Bad & Medium & Bad & Less \\
\hline Increasing & \multicolumn{2}{|c|}{3.214} & \multicolumn{2}{c|}{1.271} \\
\hline Effectiveness (\%) & \multicolumn{2}{|c|}{46.99} & \multicolumn{2}{c|}{24.99} \\
\hline
\end{tabular}

Where: $\mathrm{U} 1=$ pretest and $\mathrm{U} 2=$ posttest

Increasing the score $(\Delta \mathrm{E})$ is the difference between pretest and posttest score (U2-U1).

The effectiveness level of the learning model is the increasing of the scores of each model and minus to the increasing of score in the control class or $(\Delta \mathrm{E} / \mathrm{U} 2) \times 100 \%$.

Table 4 shows that there is a difference in the score increasing between the experimental class II and the control class by score of 3.214 for PBM model and 1.271 for control class.

And then, the results of pretest and posttest in control class and experimental class were analyzed using the anacova statistic test, by controlling the pretest, shows that there is a significant effect of the PBM model on the science process $(\mathrm{F}=$ 24.636; $\mathrm{p}=0.000$ ). The result of the difference significance test of the influence of PBM model compare to control class is presented in table 5 .

Table 5. Results of Significance Test of Model Influence to Science Process

\begin{tabular}{|l|l|c|c|}
\hline \multicolumn{2}{|c|}{ Class } & Sig & Description \\
\hline Experiment II (PBM) & Control & 0.001 & Significant \\
\hline
\end{tabular}

Table 5 shows that there is a significant difference between the experimental class II (PBM) and the control class by the p score less than 0.05 . The effectiveness test result of the difference of learning model toward the science process shows the PBM model is significantly more effective compare to the control class.

\section{Influence of implementation of cooperative learning of Group Investigation type to Student Science Process}

Based on the calculation of the total score of science process obtained average score of postest in the cooperative learning of Group Investigation type of 6.73 with the category of medium and the control class obtained score of 5.09 with the category of less. 
The calculation results of the pretest - posttest of students' science process are presented in Table 6.

Table 6. Calculation of Average score of Pretest-Posttest of Student Science Process in cooperative learning of Group Investigation type and Control

\begin{tabular}{|l|c|c|c|c|}
\hline \multirow{2}{*}{} & \multicolumn{2}{|c|}{$\begin{array}{c}\text { cooperative learning of } \\
\text { Group Investigation type }\end{array}$} & \multicolumn{2}{c|}{ Control } \\
\cline { 2 - 5 } & U1 & U2 & U1 & U2 \\
\hline Average Score & 3.597 & 6.226 & 3.814 & 5.086 \\
\hline Description & Bad & Medium & Bad & Less \\
\hline Increasing & \multicolumn{2}{|c|}{2.629} & \multicolumn{2}{c|}{1.271} \\
\hline Effectiveness (\%) & \multicolumn{2}{|c|}{42.23} & 24.99 \\
\hline
\end{tabular}

Where: $\mathrm{U} 1=$ pretest and $\mathrm{U} 2=$ posttest

Increasing the score $(\Delta \mathrm{E})$ is the difference between pretest and posttest score (U2-U1).

The effectiveness level of the learning model is the increasing of the scores of each model and minus to the increasing of score in the control class or $(\Delta \mathrm{E} / \mathrm{U} 2) \times 100 \%$.

Table 6 shows that there is a difference in the score increasing between the experimental class I and the control class by score of 2.629 for cooperative learning of Group Investigation type and 1.271 for control class.

And then, the results of pretest and posttest in control class and experimental class were analyzed using the anacova statistic test, by controlling the pretest, shows that there is a significant effect of the cooperative learning of Group Investigation type on the science process $(\mathrm{F}=9.361 ; \mathrm{p}=0.000)$. The result of the difference significance test of the influence of cooperative learning of Group Investigation type compare to control class is presented in table 7 .

Table 7. Results of Significance Test of Model Influence to Science Process

\begin{tabular}{|l|l|c|c|}
\hline \multicolumn{2}{|c|}{ Class } & Sig & Description \\
\hline $\begin{array}{l}\text { Experiment III (cooperative } \\
\text { learning of Group } \\
\text { Investigation type) }\end{array}$ & Kontrol & 0.030 & Significant \\
\hline
\end{tabular}

Table 7 shows that there is a significant difference between the experimental class III and the control class by the $\mathrm{p}$ score less than 0.05 . The effectiveness test result of the difference of learning model toward the science process shows the cooperative learning of Group Investigation type is significantly more effective compare to the control class.

\section{DISCUSSION}

The average score of posttest in Inquiry group obtained an average score of 6.734 higher than the average score of control group of 5.086 with a significant difference $(\mathrm{p}=$ $0.000<0.05)$. Based on the data, it may take conclution that the implementation of inquiry model has a significant influence on the skill of students' science process. In other words, the inquiry model is more effective than the traditional model in improving the students' science process on the concept of nutrient food. The results of the study are appropriate to 
the research results conducted by Nurjanah \& Suwarna (2011) that the inquiry group score (6.561) is higher compare to control class (5.473) toward the skill of science process on the concept of heat with significant differences ( $\mathrm{t}$ count $=4.35>\mathrm{t}$ table $=2.00$ ).

The inquiry model is the concept of constructivism where the students are encouraged to build their own knowledge based on the knowledge they possess. Merrill (1991) and Smorgansbord (1997) in Yulaelawati (2010) argue the constructivism is knowledge that builds based on the prior experience or knowledge. The constructivist characteristic is; learning is an active process where the knowledge is developed on the basis of experience and meaning negotiation through sharing information or seeking agreement from various perspectives through interaction or cooperation with others.

The average score of posttest of science process skill on the PBM model obtained of 6.84 higher than the average score of control group of 5.09 with significant difference $(\mathrm{p}=$ $0.000<0.05$ ). Based on the data, it may conclude that the PBM model is more effective when compare to the traditional model in improving the students' science process on the concept of nutrient food. The results of the study are appropriate to the research results conducted by Inel \& Balim (2010) that the average score of PBM group (25.55) is higher than control group (16.67) with significant difference $(\mathrm{p}=0.017<0.05)$.

Schafersman (1999) in Inel \& Balim (2010) found that the learning with problemsolving approaches on math and science subjects is able to improve the students' critical thinking skills. The components of critical thinking skills that must be learned by students; include the skills to (1) formulating problem, (2) giving argument, (3) making deductions, (4) making induction, (5) evaluating, and (6) deciding and implementing. By the learning activities in the PBL model and the critical thinking skills component, the PBL model may train the students' critical thinking skills. The argument supports the research results by Proulx (2004) in Inel \& Balim (2010) states that the stages of critical thinking are the same as the stages of the implementation of the scientific method, and by train the implementation of scientific method or scientific process which is the core of the PBL model, and then the learning may train the critical thinking skills.

Characteristic of the problem-based learning is; the students deliver questions or problems, and according to yazdani (2002) in Nur (2011) problem-based learning makes the problem-solving skills of students. In the PBM syntax, students conduct activities through the stages of producing a real work, and then display the work, in the implementation of the PBM model, the work of students is tables of observations result that made by students. Student activities in making the observation table requires a higher order thinking skills for elementary school students, it is appropriate to the learning outcomes based on the problem according to Nur (2011) states that the learning outcomes is students' critical thinking skills.

The average score of posttest on science process skills on cooperative learning of Group Investigation type obtained a score of 6.23 higher than average score of control group of 5.09 , with significant difference $(p=0.030<0.05)$. Based on the data, it may conclude that cooperative learning of Group Investigation type is more effective when compare to the traditional model in improving the students' science process on the concept of nutrient food. The results of the study are appropriate to the results of a study conducted by Muhibbah (2009) that the average score of cooperative learning of Group Investigation type (7.61) is higher than the average score of control group (7.01) with significant difference $(t=5.20>t$ table $=2.02)$ on the subject matter of physics, chemical and mixture separation. The similar research results also conducted by Doymus (2009) that the average 
score of cooperative learning of Group Investigation type (6.80) is higher than the average score of control group (6.24) with significant difference $(\mathrm{p}=0.018<0.05)$.

The cooperative learning of Group Investigation type is more effective than the traditional model because cooperative learning of Group Investigation type is able to more actively engage the learners in working together to investigate the problems and information related to the material concept. Since the introduction stage of learning process, students have been actively involved by way the teachers and students identify the topics of problems that will solve through the stages of investigation. An important element of cooperative strategy that able to train students' critical thinking skills is learning of social skills related to leadership, decision making, trust building, communication, and problem solving.

The cooperative learning of Group Investigation type is the most complex of cooperative strategy. The strategy is appropriate to projects that are integrated with problem solving. In the cooperative learning of Group Investigation type, students choose their topics drawned from the general theme, and then decide the way to conduct the investigation. Thus, the cooperative learning of Group Investigation type is appropriate to train the critical thinking skills. The argument supports the opinion of Slavin (1995) argue that cooperative group investigation strategies are very good to train the students' abilities, which are analysis, synthesis, and information collecting to solve the problems. And, the cooperative learning of Group Investigation type may use to train the students' high order thinking skills.

However, the effectiveness of cooperative learning of Group Investigation type is lower when compare to Inquiry model and PBM in the score of students' science process. It is because the cooperative learning of Group Investigation type emphasizes more on cooperative process in groups than the skill development to process the information with science process skills. The best suggestion is merging the Inquiry or PBM model with cooperative learning of Group Investigation types, and then, the students' skills of processing information and cooperation is able to develop simultaneously.

\section{CONCLUSION}

Based on the research results and discussion about the influence of implementation of Inquiry model, Problem Based Learning, cooperative learning of Group Investigation types toward the student science process, concluded:

1. There is significant influence of implementation the inquiry model to the student science process $(\mathrm{F}=34.978 ; \mathrm{p}=0.000)$.

2. There is significant influence of implementation the PBM model to the student science process $(\mathrm{F}=24.636 ; \mathrm{p}=0.000)$.

3. There is significant influence of implementation of cooperative learning of Group Investigation types to the student science process $(\mathrm{F}=9.361 ; \mathrm{p}=0.030)$.

Based on the conclusions, it is suggested to further researchers who want to replicate the research on the influence of inquiry model, PBM and cooperative learning of Group Investigation types, needs a measurement technique that combines the written test and the practice assessment of the science process in order the obtained data is complete and accurate.

\section{REFERENCES}

Badan Standar Nasional Pendidikan (BSNP). Panduan Penyusunan Kurikulum Tingkat Satuan Pendidikan Jenjang Pendidikan Dasar dan Menengah. Jakarta: Depdiknas. 
2006. (National Board of Education Standard. Guidance to arranging the Kurikulum Tingkat Satuan Pendidikan (KTSP curriculum) of primary and secondary school. Jakarta: National education board. 2006.)

Badan Penelitian dan Pengembangan. Penguatan Metodologi Pembelajaran Berdasarkan nilai-nilai Budaya untuk membentuk daya saing dan karakter Bangsa. Jakarta: Kementerian Pendidikan Nasional. 2010. (Agency for Research and Development. Strengthening the Learning Methodology Based on Culture values to form the competitiveness and character of the Nation. Jakarta: Ministry of National Education. 2010.)

Carin dan Bass. Teaching Science As Inquiry, New Jersey: Merril Prentice Hall. 2001. (Carin and Bass. Teaching Science As Inquiry, New Jersey: Merril Prentice Hall. 2001.)

Departemen Pendidikan Nasional. Peraturan menteri Pendidikan Nasional No 41 tahun 2007 Tentang standar proses. Jakarta: Depdiknas. 2007. (National Education Board. Minister of National education regulation (permendiknas) no 41 year 2007 about the process standard. Jakarta: National education board. 2007)

Doymus. Journal of Turkish Science Education. Volume 7, Issue 2, June 2010.

Elfis. Model pembelajaran Group Investigation dan Kooperatif (http://ahmadsyahbio.com/2010/02/model-pembelajaran-group-

investigation.html,diakses 2 Agustus 2011). 2010. (Elfis. Learning model of Group Investigation and cooperative. Retrived from http://ahmadsyahbio.com/2010/02/model-pembelajaran-group-investigation.html, accessed on 2 Agustus 2011. 2010.)

Endahsari, Triana. Karya ilmiah. (http://karyailmiah.um.ac.id/ index.php/biologi/article/view/6237. Diakses 2 Juni 2011). 2009. (Endahsari, Triana. Scientific Work. Retrieved from: (http://karyailmiah.um.ac.id/ index.php/biologi/article/view/6237. accessed on 2 june 2011. 2009.

Hadnyana, Putra Gede. Penerapan Model Pembelajaran Berdasarkan Masalah. http://putradnyanagede.blogspot.com/2011/04/penerapan-model-pembelajaran-

berbasis.html. 2011. (Hadnyana, Putra Gede. The implementation of problem based learning. Retrieved from: http://putradnyanagede.blogspot.com/2011/04/penerapanmodel-pembelajaran-berbasis.html. 2011.)

Hibbard, Michael. Performance Assessment in Middle school Science. New York: Glencoe. 1995.

Ibrahim, Muslimin. (http://herfis.com/2009/07/Pembelajaran inkuiri.html. Diakses 24 Oktober 2009). 2007. (Ibrahim, Muslimin. (retrieved from: http://herfis.com/2009/07/Pembelajaran inkuiri.html, accessed on 24 October 2009. 2007.)

Inel, Didem \& Balim, Ali Günay. Asia-Pacific Forum on Science Learning and Teaching. Volume 11, Issue 2, Article 1 (Dec., 2010). (2010)

Johnson, D.W \& Johnson, R.T. 2002. Meaningful Assessment. A Manageable and Cooperative process. Boston: Allyn \& Bacon. 
Kunandar. Guru profesional: Implementasi KTSP dan persiapan menghadapi sertifikasi guru. Jakarta: Raja Grafindo Persada. 2011. (Kunandar. Professional Teachers: KTSP Implementation and preparation for teacher certification. Jakarta: Raja Grafindo Persada. 2011.)

Kiranawati. Metode Investigasi Kelompok (Group Investigation). http: //gurupkn.wordpress.com/ 2007/11/13/ metode-investigasi-kelompok-groupinvestigation/. Diakses tgl 13 November 2007). 2007. (Kiranawati. Group Investigation method. Retrieved from http: //gurupkn.wordpress.com/ 2007/11/13/ metode-investigasi-kelompok-group-investigation/, accessed on 13 November 2007,. 2007.

Nur, Mohamad. Model Pembelajaran Berdasarkan Masalah. Surabaya: Universitas Negeri Surabaya. 2011. (Nur, Mohamad. Model of problem based learning. Surabaya: Surabaya State University. 2011.)

Nurjanah \& Suwarna. Pengaruh penerapan model inkuiri terhadap keterampilan proses sains. (http://iwanps.wordpress. com/2011/01/04/ -model-pembelajaran-inkuiriterhadap-keterampilan-proses-sains-kps-pada-konsep-kalor. diakses 23 September 2011). 2011. (Nurjanah \& Suwarna. Pengaruh The Influence of implementation of inquiry model to science process skill. (retrieved from: http://iwanps.wordpress. com/2011/01/04/ -model-pembelajaran-inkuiri-terhadap-keterampilan-proses-sainskps-pada-konsep-kalor, accessed on 23 September 2011). 2011.)

Nurhadi dkk. Pembelajaran Kontekstual dan Penerapannya dalam KBK. Malang: Universitas Negeri Malang. 2003. (Nurhadi et al. Contextual learning and its implementation on KBK. Malang: Malang State University. 2003.)

Romanesca. Keterampilan proses sains. (http://romanescareyza.com/2011/04/ketrampilan proses-sains.html Diakses Senin, 18 April 2011). 2011. (Romanesca. Skill of science process. (retrieved from: http://romanescareyza.com/2011/04/ketrampilan proses-sains.html accessed on monday, 18 April 2011). 2011.)

Rossi,P.H, Lipsey, M.W \& Freeman,H.E. Evaluation: A Systematic Approach. USA: SAGE Publications. 2004.

Sampson \& Gleim. Argument-Driven Inquiry To Promote the Understanding of Important Concepts \& Practices in Biology. Jurnal The American biology Teacher Oktober 2009. 2009.

Science Education Quality Improvement Project team (Tim SEQIP). Buku IPA guru kelas V. Jakarta: Depdiknas. 2000. (Science Education Quality Improvement Project team (SEQIP Team). Book of science teacher of class $V$. Jakarta: National education board. 2000.)

Slavin, Robert E. Cooperative Learning. Diterjemahkan oleh nurulita. Bandung: Nusa Media. 2013. (Slavin, Robert E. Cooperative Learning. Translated by nurulita. Bandung: Nusa Media. 2013.) 